\title{
Faktor Fundamental, Suku Bunga, Nilai Tukar dan Return Saham Perusahaan Sektor Industri Barang Konsumsi
}

Basis G. Andamari ${ }^{1}$

${ }^{1}$ Universitas Pancasila, Jl, Raya Lenteng Agung, Jagakarsa, Jakarta Selatan, 12640

I N F O A R T I K E L

JEL Classification:

G14

G10

\section{Keywords:}

Return on Equity (ROE), Debt Equity of Ratio (DER), Earning per Share Log(EPS), Suku bunga, Nilai Tukar dan Return Saham.

\section{A B S T R A C T}

This study aims to examine the effect of return on equity, debt equity ratio, earnings per share, interest rates and the Exchange Rate To return under common control. Sample is the company-consumer goods industry sector company listed on the Indonesian Stock Exchange 2008-2011. Testing is done by multiple linear regression. Test results showed that the earnings per share and interest rates showed a significant influence under common thing against return. Return on equity, debt to equity ratio, Exchange Rate indicates the findings of no effect. Results showed that the accounting information is a prayer One That information is used to review adopted a decision to invest. Future research is recommended to review conduct tests with samples of different industries and adding new accounting information in addition to that already examined.

\section{A B S T R A K}

Penelitian bertujuan menguji pengaruh return on equity, debt equity of ratio, earning per share, suku bunga dan nilai tukar terhadap return saham. Sampel adalah perusahaan-perusahaan sektor industri barang konsumsi yang terdaftar di BEI tahun 2008-2011. Pengujian dilakukan dengan regresi linier berganda. Hasil pengujian menunjukkan bahwa earning per share dan suku bunga menunjukkan pengaruh yang signifikan terhadap return saham. Return on equity, debt to equity ratio, nilai tukar menunjukkan hasil tidak berpengaruh. Hasil penelitian menunjukkan bahwa informasi akuntansi merupakan salah satu informasi yang digunakan untuk mengambil keputusan berinvestasi. Penelitian mendatang disarankan untuk melakukan pengujian dengan sampel industri berbeda dan menambahkan informasi akuntansi baru selain yang telah diteliti.

\section{Pendahuluan}

Perusahaan dan investor memerlukan data untuk mengetahui faktor-faktor apa saja yang berpengaruh positif signifikan terhadap return saham, dan sektor apa yang relatif sedikit dipengaruhi oleh perubahan ekonomi makro. Obyek penelitian riset ini adalah sektor industri barang konsumsi karena sektor ini fluktuasi harga sahamnya relatif stabil dibandingkan sektor lain yang tergambar dalam IHSG. Hal ini disebabkan sektor konsumsi banyak berkecimpung di pasar domestik sehingga sedikit dipengaruhi oleh keadaan ekonomi makro.

Ang (1997) berpendapat, ada dua faktor yang mempengaruhi return saham yaitu pertama, 
faktor fundamental (internal/mikro) perusahaan seperti kualitas dan reputasi manajemennya, struktur permodalannya, struktur hutang perusahaan, profitabilitas dan sebagainya; kedua adalah menyangkut faktor eksternal (makro), misalnya pengaruh kebijakan moneter dan fiskal, perkembangan sektor industrinya sebagai contoh: tingkat inflasi, produk domestik bruto, nilai tukar mata uang domestik terhadap mata uang asing, tingkat suku bunga dan sebagainya.

Analisis fundamental adalah metode analisis yang didasarkan pada fundamental ekonomi (keuangan) suatu perusahaan. Teknis ini menitikberatkan pada rasio finansial dan kejadian - kejadian yang secara langsung maupun tidak langsung mempengaruhi kinerja keuangan perusahaan. Menurut Wira (2011:7), kita harus melakukan analisa fundamental karena faktor fundamental adalah faktor utama penggerak harga saham dalam jangka panjang. Sahamsaham dengan fundamental baik harganya cenderung terus meningkat dalam jangka panjang meskipun dalam perjalanannya mengalami naik dan turun yang dipengaruhi oleh berita positif dan negatif. Selain itu kemampuan perusahaan dalam membayar dividen ke investor banyak dipengaruhi oleh profitabilitas dan kebijaksaan investasi yang terlihat di analisa fundamental. Terakhir analisa dapat membantu meminimalkan risiko, sejarah pasar modal sudah membuktikan bahwa saham-saham dengan fundamental baik harganya segera kembali saat terjadi kejatuhan harga pada saat terjadi krisis ekonomi atau koreksi pasar.

Faktor fundamental yang dipilih adalah ROE (Return on Equity), DER (Debt to Equity Ratio) dan EPS Log (Earning Per Share Log). ROE dan EPS merupakan hal yang penting bagi perusahaan dan investor karena secara teoritis jika ROE dan EPS meningkat makan Return Saham-pun meningkat. DER merupakan bahan pertimbangan dimana sebaiknya DER < 1 karena DER yg tinggi mengakibatkan biaya yang tinggi sehingga dapat menurunkan Return Saham. Menurut pendapat Wira (2011:72), ROE digunakan untuk mengukur tingkat profitabilitas perusahaan. Sedangkan pendapat
Fahmi (2011:137), ROE disebut juga dengan laba atas equity. Rasio ini mengkaji sejauh mana suatu perusahaan mempergunakan sumber daya yang dimiliki untuk mampu memberikan laba atas ekuitas. Sutrisno menyatakan bahwa ROE merupakan kemampuan perusahaan dalam menghasilkan keuntungan dengan modal sendiri yang dimiliki. Secara historis, perusahaan yang menguntungkan adalah perusahaan yang memiliki ROE tinggi. Namun menurut pendapat Susilowati dan Turyanto (2011) dalam penelitiannya, Return on Equity tidak berpengaruh signifikan terhadap return saham.

DER menurut Sutrisno (2009:218) merupakan perbandingan antara hutang yang dimiliki perusahaan dengan modal sendiri. Semakin tinggi rasio ini berarti modal sendiri semakin sedikit dibanding dengan hutangnya. Bagi perusahaan sebaiknya hutang tidak boleh melebihi modal sendiri agar beban tetapnya tidak terlalu tinggi, kecuali perusahaan di sektor keuangan. Beberapa penelitian menyatakan tentang DER yaitu : Dewi (2005), DER secara partial tidak berpengaruh signifikan terhadap total return, sedangkan secara bersama-sama ROA, DER, PBV, PER dan Volume Perdagangan terbukti signifikan berpengaruh terhadap total return. Faried (2008), DER tidak mempunyai pengaruh signifikan terhadap return saham. Nathaniel (2008), DER berpengaruh tidak signifikan terhadap return saham. Prihantini (2009), DER berpengaruh negatif dan signifikan terhadap return saham. Subalno, SE (2009), DER pengaruhnya tidak signifikan terhadap return saham. Susilowati dan Turyanto (2011), DER berpengaruh signifikan terhadap return saham.

EPS merupakan ukuran kemampuan perusahaan untuk menghasilkan keuntungan per lembar saham pemilik (Sutrisno, 2009:223). Berbeda-beda juga hasil penelitian sebelumnya tentang EPS. Nathaniel (2008) dan Susilowati dan Turyanto (2011), menyatakan EPS berpengaruh tidak signifikan terhadap return saham. Subalno (2009), EPS tidak dapat dijadikan sebagai acuan dalam menentukan strategi investasi para investor dalam menanamkan sahamnya di pasar modal.

Menurut Wira (2011;16), dengan memahami kondisi makro ekonomi negara maka 
kita akan dapat menentukan apakah akan menginvestasikan dana ke pasar saham atau tidak. Hal ini disebabkan kondisi pasar saham berkaitan erat dengan kondisi ekonomi negara yang bersangkutan. Disaat ekonomi suatu negara sedang bertumbuh maka pasar saham juga bullish, sedangkan saat ekonomi negara sedang terpuruk, pasar saham juga bearish.

Salah satu variabel ekonomi yang selama ini dipercaya terkait secara cukup kuat terhadap kinerja pasar modal Indonesia adalah perubahan tingkat suku bunga. Penurunan pada tingkat suku bunga akan mendorong pengeluaran konsumsi dan investasi yang selanjutnya akan meningkatkan harga saham (Modigliani, 1971; Durham, 2000 dalam Lestari, 2005). Jensen dan Johnson (1995) mengemukakan bahwa perubahan tingkat suku bunga akan menimbulkan reaksi yang bervariasi pada berbagai sektor industri yang berbeda. Kenaikan suku bunga dapat pula mendorong pergeseran investasi dari saham ke obligasi dan sebaliknya. Utami dan Rahayu (2003) berpendapat suku bunga mempunyai hubungan negatif terhadap harga saham. Meta (2006), tingkat suku bunga tidak berpengaruh terhadap return saham properti namun berpengaruh negatif terhadap return saham manufaktur. Subalno, SE (2009), suku bunga SBI berpengaruh signifikan terhadap return saham. Ath Thobarry (2009), suku bunga hanya signifikan bila diuji secara bersamaan dan tidak berpengaruh signifikan bila diuji secara parsial. Suramaya Kewal (2012) berpendapat, suku bunga SBI tidak berpengaruh terhadap IHSG.

Fluktuasi nilai tukar suatu mata uang juga dapat mempengaruhi kegiatan dan nilai pasar atas pasar lokal, jika perusahaan pada taraf persaingan internasional, hal ini berarti return saham perusahaan dipengaruhi oleh perubahan nilai tukar mata uang karena berdampak terhadap laporan perdagangan dan modal atas keseimbangan pembelian dalam negeri. Nilai tukar rupiah yang rendah juga akan mendorong melemahnya daya beli masyarakat yang dapat memicu kurang menariknya tingkat investasi dalam rupiah. Hardiningsih (2001) menyatakan bahwa nilai tukar mata uang domestik terhadap mata uang asing mempunyai pengaruh yang negatif terhadap return saham. Menurut Utami dan Rahayu (2003), Nilai tukar rupiah terhadap dollar mempunyai hubungan yang positif terhadap return saham. Meta (2006), kurs Rupiah/US Dollar berpengaruh signifikan negatif terhadap return saham properti dan manufaktur. Prihantini Ratna (2009), nilai tukar berpengaruh negatif dan signifikan terhadap return saham. Subalno, SE (2009) berpendapat nilai tukar berpengaruh signifikan terhadap return saham. Ath Thobarry (2009), nilai tukar memiliki pengaruh positif signifikan terhadap return saham dan Kewal (2012) berpendapat kurs berpengaruh secara signifikan terhadap IHSG. Berdasarkan temuan beberapa penelitian sebelumnya yang belum konsisten, penelitian ini pengaruh ROE, DER, EPS, suku bunga dan nilai tukar terhadap return saham.

\section{Telaah Teori dan Pengembangan Hipotesis}

Teori keagenan, Jensen dan Meckling (Jensen, 1976) mendefinisikan hubungan keagenan sebagai sebuah kontrak dimana satu atau lebih (principal) menyewa orang lain (agent) untuk melakukan beberapa jasa untuk kepentingan mereka dengan mendelegasikan beberapa wewenang pembuatan keputusan kepada agen. Menurut Wolk, et al. dalam Jama'an (2008), teori sinyal menjelaskan alasan perusahaan menyajikan informasi untuk pasar modal. Teori sinyal menunjukkan adanya asimetri informasi antara manajemen perusahaan dan pihal-pihak yang berkepentingan dengan informasi tersebut. Teori sinyal mengemukakan tentang bagaimana seharusnya perusahaan memberikan sinyal-sinyal pada pengguna laporan keuangan.

Investasi adalah penempatan sejumlah dana pada saat ini dengan tujuan untuk memperoleh keuntungan dimasa yang akan datang (Halim, 2005). Tandelilin (2010) berpendapat bahwa investasi adalah komitmen atas sejumlah dana atau sumberdaya lainnya yang dilakukan pada saat ini dengan tujuan memperoleh keuntungan dimasa yang akan datang. Aktivitas investasi pada umumnya dilakukan pada aset 
riil seperti tanah, emas, mesin dan bangunan maupun asset finansial seperti saham, obligasi dan deposito. Saham adalah bentuk paling murni dan sederhana dari kepemilikan perusahaan (Gitman, 2000:7). Darmadji dan Fakhruddin (2008) menyatakan bahwa saham itu suatu surat berharga yang menunjukkan adanya kepemilikan seseorang atau badan hukum terhadap perusahaan penerbit saham.

Pasar modal adalah tempat bertemunya penjual dan pembeli untuk melakukan transaksi saham, obligasi dan produk pasar modal lainnya. Menurut Jogiyanto (2010:29) pasar modal merupakansaranaperusahaanuntukmeningkatkan kebutuhan dana jangka panjang dengan menjual saham atau mengeluarkan obligasi. Menurut pendapat Darmaji dan Fakhruddin (2008), analisa fundamental merupakan salah satu cara dalam melakukan penilaian saham dengan mempelajari atau mengamati berbagai indikator terkait kondisi mikro ekonomi dan kondisi industri suatu perusaaan, termasuk berbagai indikator keuangan perusahaan.

Menurut Wira $(2011,7)$ untuk mengetahui kondisi fundamental perusahaan biasanya dilakukan dengan menggunakan rasio-rasio keuangan. Rasio secara garis besar di bagi dalam 5 kategori utama antara lain, yaitu :

\section{Profitability Ratio}

Rasio ini digunakan untuk mengetahui kemampuan perusahaan menghasilkan laba. Rasio yang digunakan dalam penelitian ini adalah: Return on Equity ( ROE ) ROE merupakan ukuran kemampuan perusahaan (emiten) dalam menghasilkan keuntungan dengan menggunakan modal sendiri, sehingga ROE ini sering disebut sebagai rentabilitas modal sendiri. Rasio ini diperoleh dengan membagi laba setelah pajak dengan modal sendiri. Semakin tinggi ROE menunjukkan kinerja perusahaan semakin baik dan berdampak pada meningkatnya harga saham perusahaan. maka secara teoritis, sangat dimungkinkan ROE berpengaruh positif terhadap return saham.

\section{Debt Ratio}

Menurut Riyanto (2001:32), rasio utang dimaksudkan sebagai kemampuan suatu perusahaan untuk membayar semua utangutangnya (baik hutang jangka pendek maupun utang jangka panjang). Pembiayaan dengan utang, memiliki Rasio yang digunakan dalam penelitian ini adalah: Debt to Equity Ratio (DER) Semakin tinggi DER menunjukkan semakin besar total hutang terhadap total ekuitas (Ang, 1997), juga akan menunjukkan semakin besar ketergantungan perusahaan terhadap pihak luar (kreditur) sehingga tingkat resiko perusahaan semakin besar. Hal ini membawa dampak pada menurunnya harga saham di bursa, sehingga return saham akan menurun.

3. Market Ratio

Menurut pendapat Wira (2011:77), rasio ini umumnya digunakan untuk mengetahui relatif hubungan antara harga saham dan kondisi keuangan perusahaan. Rasio yang digunakan dalam penelitian ini adalah: Earning Per Share (EPS ) Fahmi (2011:138), EPS atau pendapatan per lembar saham adalah bentuk pemberian keuntungan yang diberikan kepada para pemegang saham dari setiap lembar yang dimiliki.

Pemahaman terhadap kondisi makro ekonomi negara maka kita akan dapat menentukan apakah akan menginvestasikan dana ke pasar saham atau tidak. Hal ini disebabkan kondisi pasar saham berkaitan erat dengan kondisi ekonomi negara yang bersangkutan.

Dalam penelitian ini faktor makro yang akan diteliti yaitu suku bunga dan nilai tukar.

1. Suku Bunga

Tingkat suku bunga atau interest rate merupakan rasio pengembalian atas sejumlah investasi sebagai bentuk imbalan yang diberikan kepada investor (Suad Husnan, 2005).

2. Nilai Tukar

Pengertian nilai tukar mata uang menurut FASB adalah rasio antara suatu unit mata uang dengan sejumlah mata uang lain yang bisa ditukar pada waktu tertentu.

Melemahnya nilai tukar domestik terhadap mata uang asing (seperti rupiah terhadap 
dollar) memberikan pengaruh yang negatif terhadap pasar ekuitas karena pasar ekuitas menjadi tidak memiliki daya tarik.

Jogiyanto (2010:205) berpendapat return merupakan hasil yang diperoleh dari investasi. Return dapat berupa return realisasian yang sudah terjadi atau return. Return saham adalah hasil dari capital gain (harga jual-harga beli) ditambah deviden.

\section{Pengaruh Return on Equity terhadap Return Saham}

ROE merupakan ukuran kinerja perusahaan ditinjau dari segi profitabilitasnya, yaitu kemampuan menghasilkan laba bersih setelah pajak relatif terhadap modal yang dimiliki oleh perusahaan. ROE yang semakin meningkat menyebabkan investor semakin tertarik untuk menanamkan dananya ke dalam perusahaan tersebut. Pertumbuhan modal perusahaan. Namun menurut pendapat Wijaya, secara simultan ROE signifikan dan positif tidak memiliki pengaruh terhadap return saham dan secara parsial ROE juga tidak memiliki pengaruh secara signifikan dan positif terhadap return saham, demikian juga dengan Susilowati dan Turyanto (2011), mereka berpendapat bahwa ROE tidak berpengaruh signifikan terhadap return saham.

H1: ROE berpengaruh positif terhadap return saham.

\section{Pengaruh Debt to Equity Ratio terhadap Return Saham}

DER dipergunakan untuk mengukur tingkat penggunaan utang terhadap total shareholders' equity yang dimiliki perusahaan. Total debt merupakan total liabilities (jangka pendek/jangka panjang), sedangkan total shareholder equity menunjukkan total modal sendiri yang dimiliki perusahaan. Perusahaan yang sedang berkembang dan tumbuh memerlukan sumber pendanaan untuk mendanai operasional perusahaan. Perusahaan tersebut memerlukan banyak dana operasional yang tidak mungkin dapat dipenuhi hanya dari modal sendiri yang dimiliki perusahaan. Akan tetapi DER yang tinggi menyebabkan biaya bunga juga tinggi sehingga pengaruh DER terhadap return saham adalah negatif. Namun pendapat penelitipeneliti yang lain Faried (2008) membuktikan secara partial DER tidak mempunyai pengaruh signifikan terhadap return saham. Dewi (2005) - Secara partial DER menunjukkan hasil yang tidak berpengaruh signifikan terhadap Total Return. Sedangkan secara simultan DER terbukti signifikan berpengaruh terhadap Total Return. Nathaniel(2008) menemukan DER berpengaruh tidak signifikan terhadap return saham. Subalno (2009) menemukan DER tidak berpengaruh signifikan terhadap return saham. Hasil penelitian Susilowati dan Turyanto (2011) menunjukkan DER berpengaruh signifikan terhadap return saham.

H2: DER berpengaruh negatif terhadap return saham.

\section{Pengaruh Earning Per Share terhadap Return Saham}

EPS merupakan rasio yang menggambarkan tingkat laba yang diperoleh oleh para pemegang saham, dimana tingkat laba (per lembar saham) menunjukkan kinerja perusahaan terutama dari kemampuan laba yang dikaitkan dengan pasar. EPS menunjukkan bahwa semakin besar tingkat kemampuan perusahaan dalam menghasilkan keuntungan per lembar saham bagi pemiliknya, maka hal akan mempengaruhi return saham perusahaan tersebut di pasar modal. Oleh sebab itu, perusahaan yang stabil akan memperlihatkan stabilitas pertumbuhan EPS, sebaliknya perusahaan yang tidak stabil akan memperlihatkan pertumbuhan yang fluktuatif.

EPS merupakan perbandingan antara jumlah earning after tax (EAT) dengan jumlah saham yang beredar. EPS merupakan salah satu rasio keuangan yang sering digunakan oleh investor untuk menganalisa kemampuan perusahaan menghasilkan laba berdasarkan saham yang dimiliki (Hanafi, 1996). EPS merupakan komponen penting yang harus diperhatikan dalam analisa perusahaan, karena informasi EPS suatu perusahaan menunjukkan besarnya laba bersih perusahaan yang siap dibagikan kepada semua pemegangsahamdengankatalainmenggambarkan prospek earning perusahaan di masa mendatang. 
Besarnya EPS dapat diketahui dari informasi laporan keuangan perusahaan (Tandelin, 2010). Semakin besar EPS akan menarik investor untuk melakukan investasi diperusahaan tersebut. Oleh karena itu, hal tersebut akan mengakibatkan permintaan akan saham meningkat dan harga saham akan meningkat, dengan demikian EPS berpengaruh positif terhadap return saham. Penelitian Wulandari (2005) juga mendukung teori tersebut dimana EPS berpengaruh positif dan signifikan terhadap return saham.

H3: EPS berpengaruh positif terhadap return saham.

\section{Pengaruh Tingkat Suku Bunga terhadap Return Saham}

Tingkat suku bunga atau interest rate merupakan rasio pengembalian atas sejumlah investasi sebagai bentuk imbalan yang diberikan kepada investor (Husnan, 2005). Besarnya tingkat suku bunga bervariatif sesuai dengan kemampuan debitur dalam memberikan tingkat pengembalian kepada kreditur. Tingkat suku bunga tersebut dapat menjadi salah satu pedoman investor dalam pengambilan keputusan investasi pada pasar modal. Sebagai wahana alternatif investasi, pasar modal menawarkan suatu tingkat pengembalian (return) pada tingkat resiko tertentu. Dengan membandingkan faktor keuntungan dan resiko pada pasar modal dengan faktor tingkat suku bunga yang ditawarkan sektor keuangan, investor dapat memutuskan bentuk investasi yang mampu menghasilkan keuntungan yang optimal. Tingkat suku bunga yang meningkat akan menyebabkan peningkatan suku bunga yang diisyarakatkan atas investasi pada suatu saham. Di samping itu tingkat suku bunga yang meningkat bisa juga menyebabkan investor menarik investasinya pada saham dan memindahkannya pada investasi berupa tabungan ataupun deposito (Tandelilin, 2010) Kenaikan tingkat suku bunga sektor keuangan diprediksikan akan memberikan pengaruh negatif terhadap harga saham (Robert Ang, 1997). Penelitian dari Utami dan Rahayu (2003) serta Subalno (2009) juga menunjukkan bahwa suku bunga mempunyai hubungan negatif terhadap harga saham.
H4: Suku Bunga berpengaruh negatif terhadap return saham.

\section{Pengaruh Nilai Tukar Rupiah terhadap Return Saham}

Kurs juga dapat didefinisikan sebagai harga 1 unit mata uang domestik dalam satuan valuta asing. Melemahnya nilai tukar domestik terhadap mata uang asing (seperti rupiah terhadap dollar) memberikan pengaruh yang negatif terhadap pasar ekuitas karena pasar ekuitas menjadi tidak memiliki daya tarik (Ang, 1997). Jika nilai tukar tetap atau menguat pengaruhnya positif terhadap return saham. Sebagaimana hasil penelitian Subalno (2009) menunjukkan bahwa nilai tukar mempunyai pengaruh signifikan positif terhadap return saham.

H5:Nilai Tukar Bruto berpengaruh positif terhadap return saham.

\section{Metode}

Penelitian ini merupakan penelitian kuantitatif yang menguji hipotesis. Tujuan penelitian menguji pengaruh return on equity, debt equity of ratio, earning per share, suku bunga dan nilai tukar terhadap return saham. Teknik sampling yang digunakan adalah purposive sampling dengan kriteria: (1) Perusahaan terdaftar dan aktif melakukan perdagangan di Bursa Efek Indonesia selama periode 2008-2011, (2) Perusahaan dimaksud mempunyai laporan keuangan yang diaudit selama periode 20082011, (3) Memiliki data harga saham berturutturut selama periode 2008-2011. Data diperoleh dari website BEI untuk periode 2008-2011. Diperoleh sampel sebanyak 27 perusahaan dari 36 perusahaan sektor industri barang konsumsi yang terdaftar di BEI. Teknis analisis yang digunakan adalah regresi linier berganda dan uji hipotesis menggunakan t-test untuk menguji pengaruh secara parsial serta F-test untuk menguji pengaruh secara simultan terhadap return saham dengan tingkat signifikansi $5 \%$. Selain itu juga dilakukan uji asumsi klasik yang meliputi uji normalitas, uji multikolinearitas, uji heteroskedastisitas dan uji autokorelasi. Pengukuran variabel didasarkan pada pengukuran yang pernah dilakukan oleh 
penelitian sebelumnya yang dirujuk pada penelitian ini.

Beberapa pengujian terkait dengan syarat uji regresi (uji asumsi klasik) dapat dijelaskan sebagai berikut.

1. Uji Normalitas

Uji normalitas bertujuan untuk menguji apakah dalam model regresi, variabel residual memiliki distribusi normal.

Uji Normalitas menggunakan Normal P-P Plot, hasilnya terlihat dalam lampiran 9, gambar 2. Grafik normal dari pola yang menunjukkan penyebaran titik-titik disekitar garis diagonal dan mengikuti arah garis diagonal, mengidentifikasikan model regresi memenuhi asumsi Normalitas

2. Uji Multikolinieritas

Uji multikolinearitas untuk menguji apakah pada model regresi ditemukan adanya korelasi antar variabel bebas (independen). Jika variabel independen saling, hasilya terlihat dalam lampiran 9,tabel 2. Tolerance $>$ 0,1 dan VIF $<10$ menunjukkan tidak terjadi multikolieritas. Nilai Eigenvalue sebesar 4,980 berada jauh diatas 0 , ini menunjukkan tidak ada pengeluaran variabel bebas, terlihat dalam lampiran 9, tabel 6.

3. Uji Heteroskedastisitas

Uji heteroskedastisitas bertujuan untuk menguji apakah dalam model regresi terjadi ketidak samaan varian dari residual satu pengamatan ke pengamatan yang lain. Hasilnya terlihat dalam lampiran 9 gambar 3. Dengan melihat sebaran titik yang acak, baik diatas maupun dibawah angka 0 dari sumbu y, dapat disimpulkan tidak terjadi heteroskedastisitas

4. Uji Autokorelasi

Uji autokorelasi bertujuan untuk menguji apakah dalam model regresi linear ada korelasi antara kesalahan pengganggu pada periode t-1 (sebelumnya). Menurut Ghozali, (2006), model regresi yang baik adalah regresi yang bebas dari autokorelasi. Untuk mengetahui ada tidaknya autokorelasi kita harus melihat nilai uji D-W, dimana:

a. $\quad \mathrm{dw}<\mathrm{dL}$ : terdapat gejala autokorelasi positif

b. $\quad d w>(4-d L)$ : terdapat gejala autokorelasi negatif

c. $\mathrm{dL}<\mathrm{dw}<\mathrm{dU}$ : pengujian tidak meyakinkan ( ragu-ragu)

d. 4-du $<\mathrm{dw}<4-\mathrm{dl}$ : pengujian tidak meyakinkan ( ragu-ragu)

e. $\quad d u<d w<(4-d U)$ : tidak terdapat gejala autokorelasi

Hasil pengujian menunjukkan nilai $\mathrm{DW}=1.96$. Diketahui: $\alpha=0,05 ; \mathrm{n}=108$ ( jumlah data) ; $\mathrm{k}=5$ (jumlah variabel bebas) nilai $\mathrm{dl}=1,586 ; \mathrm{du}=1,783 ; 4-\mathrm{du}=2,217 ; 4-\mathrm{dl}=2,414$. Tidak terjadi autokorelasi bila $\mathrm{du}<\mathrm{dw}<(4-\mathrm{du})=$ $(1,783<1,961<4-1,783)=1,783<1,961<2,217$. Berdasarkan perhitungan tersebut dapat disimpulkan bahwa tidak terjadi autokorelasi.

\section{Hasil Penelitian dan Pembahasan}

Pengujian hipotesis dilakukan setelah dilakukan uji asumsi klasik. Uji model penelitian dilakukan dengan membaca hasil uji koefisien determinasi (Adjusted R-Square) dan Uji F. Pembuktian hipotesis dilakukan berdasarkan hasil uji t. Koefisien determinasi (R2) pada intinya mengukur seberapajauh kemampuan model dalam menerangkan variasi variabel dependennya. Nilai R2 yang mendekati 1 (satu) berarti variabel-variabel independennya memberikan hampir semua informasi yang dibutuhkan untuk memprediksi variasi variabel dependen (Ghozali, 2006). Nilai koefisien determinasi (R2) sebesar 0,697. Hal ini menunjukkan bahwa besar pengaruh variabel independent yaitu ROE, DER, EPS Log Suku Bunga dan Nilai Tukar terhadap variabel dependen yaitu Return Saham adalah sebesar $69,7 \%$ dan sisanya sebesar 30,3\% dipengaruhi oleh faktor-faktor lain yang tidak dimasukkan dalam model regresi.

Uji statistik F pada dasarnya menunjukkan apakah semua variabel independen yang dimasukkan dalam model mempunyai pengaruh secara simultan terhadap variabel dependennya. Dengan tingkat keyakinan $95 \%, \alpha=0,05$, df 1 (jumlah variabel -1$)=6-1=5$, df $2(\mathrm{n}-\mathrm{k}-1)$ $=108-5-1=102$, maka diperoleh $\mathrm{F}$ tabel $=2,30$. 
Sedangkan berdasarkan penelitian diperoleh nilai $F$ hitung sebesar 46,943 sehingga $F$ hitung $>F$ tabel $(46,943>2,30)$ maka model penelitian yang diuji merupakan model yang baik. Nilai $F$ hitung sebesar 46,943 dengan nilai signifikansi sebesar 0,000. Karena probabilitas jauh lebih kecil dari 0,05 atau 5\%, maka model regresi dapat digunakan untuk memprediksi Return Saham atau dapat dikatakan bahwa ROE, DER, EPS Log, Suku Bunga dan Nilai Tukar secara simultan berpengaruh signifikan terhadap Return Saham.

Pengujian koefisien regresi secara parsial dimaksudkan untuk melihat apakah variabel independen secara individu berpengaruh terhadap variable dependen, dengan asumsi variabel independen lainnya tetap konstan. Hasil uji t-test menunjukkan signifikansi EPS $(0,000)$ dan Suku Bunga $(0,000)$ yang berarti secara parsial mempunyai hubungan signifikan terhadap Return Saham, sedangkan ROE $(0,930)$; DER $(0,278)$ dan Nilai Tukar $(0,067)$ secara parsial tidak berpengaruh secara signifikan terhadap Return Saham.

Analisis regresi linier berganda untuk memperoleh gambaran yang menyeluruh mengenai hubungan antara variabel satu dengan variabel yang lain.

$\mathrm{Y}=103,621+0,012 \mathrm{ROE}-3,429 \mathrm{DER}+16,234$

EPS-22,351SB+7,307NT+e

a. Konstanta sebesar 103,621 menyatakan bahwa jika variabel bebas dianggap konstan sama dengan 0 (nol) maka return saham nilainya sebesar 103,621

b. Koefisien regresi ROE sebesar 0,012 menyatakan bahwa setiap peningkatan ROE sebesar $1 \%$ akan menaikkan return saham sebesar 0,012 atau $1 \%$.

c. Nilai Koefisien regresi DER sebesar - 3,429 menyatakan bahwa setiap peningkatan DER sebesar 1\% akan menurunkan return saham sebesar 3,429 atau 342,9\%.

d. Koefisien regresi EPS sebesar 16,234 menyatakan bahwa setiap peningkatan EPS sebesar 1\% akan menaikkan return saham sebesar 16,234 atau 1623,482\%. e. Koefisien regresi Suku Bunga sebesar 22,351 menyatakan bahwa setiap peningkatan Suku Bunga sebesar 1\% akan menurunkan return saham sebesar - 22,351 atau 2235,1 $\%$.

f. Koefisien regresi Nilai Tukar sebesar 7,307 menyatakan bahwa setiap peningkatan Nilai Tukar sebesar 1\% akan menaikkan return saham sebesar 7,307 atau 730,7 \%.

Dengan menggunakan tingkat keyakinan $95 \%, \alpha=0,05$, df 1 (jumlah variabel -1$)=$ $6-1=5$, df $2(\mathrm{n}-\mathrm{k}-1)=108-5-1=102$, maka diperoleh $\mathrm{t}$ tabel $=1,98350$. Berdasarkan penelitian diperoleh nilai t hitung untuk ROE sebesar 2.121 sehingga $t$ hitung $>t$ tabel $(0,088$ $<1,98350)$ maka Ha ditolak artinya ROE secara parsial tidak berpengaruh secara signifikan terhadap Return Saham. Berdasarkan penelitian diperoleh nilai thitung untuk DER sebesar $(1,092)$ sehingga $t$ hitung $>t$ tabel $\quad(-1,092>-1,98350)$ maka Ha ditolak artinya DER secara parsial tidak berpengaruh secara signifikan terhadap Return Saham. Berdasarkan penelitian diperoleh nilai t hitung untuk EPS Log sebesar 5,559 sehingga $\mathrm{t}$ hitung $>\mathrm{t}$ tabel $(5,559>1,98350)$ maka $\mathrm{Ha}$ diterima artinya EPS berpengaruh positif secara signifikan terhadap Return Saham. Sedangkan berdasarkan penelitian diperoleh nilai t hitung untuk Suku Bunga sebesar - 11,509 sehingga $\mathrm{t}$ hitung $<\mathrm{t}$ tabel $\quad(-11,509<-1,98350)$ maka Ha diterima artinya Suku Bunga berpengaruh negatif secara signifikan terhadap Return Saham. Sedangkan berdasarkan penelitian diperoleh nilai t hitung untuk nilai Tukar sebesar 1,.851 sehingga t hitung $>$ t tabel $(1,851<1,98350)$ maka Ha ditolak artinya Nilai Tukar tidak berpengaruh secara signifikan terhadap Return Saham.

Berdasar hasil pengujian hipotesis pertama menunjukkan bahwa secara simultan seluruh variabel bebas yang terdiri dari ROE, DER, EPS Log, Suku Bunga dan Nilai Tukar (ribuan) berpengaruh signifikan terhadap variabel terikat yaitu Return Saham (Sig F = 0.000), hal ini sesuai dengan hipotesisnya yang menyatakan bahwa variabel-variabel independen tersebut secara simultan berpengaruh signifikan terhadap Return Saham karena Return Saham sebetulnya 
dipengaruhi oleh fundamental keuangan perusahaan dan keadaan makroekonomi. Perusahaan dengan fundamental keuangan yang lebih baik cenderung menghasilkan Return yang meningkat baik melalui capital gain (kenaikan harga saham) maupun kemampuan perusahaan dalam membayar deviden. Demikian pula keadaan ekonomim makro yang kondusif (nilai tukar stabil, suku bunga rendah \& stabil, dll) akan meningkatkan kepercayaan investor yang pada akhirnya berpengaruh meningkatkan Return Saham.

ROE tidak berpengaruh signifikan terhadap Return Saham ( Sig $\mathrm{t}=0,930$ ), hal ini tidak sesuai dengan hipotesis yang menyatakan bahwa ROE berpengaruh positif signifikan terhadap Return Saham karena ROE tidak memberikan gambaran secara langsung terhadap unjuk kerja keuangan perusahaan. Perusahaan yang masih berukuran kecil ROE cenderung meningkat dengan cepat sejalan dengan peningkatan laba bersih (earning). Akan tetapi pada tahap tertentu peningkatan pendapatan dan laba bersih hanya bisa dicapai dengan tambahan modal (equity) yang signifikan sehingga ROE cenderung "stagnant" meskipun laba bersih meningkat. Hal itu menyebabkan regresi linier dengan sample perusahaan yang mempunyai fase pertumbuhan yang berbeda memberikan hasil yang tidak signifikan.

DER tidak berpengaruh signifikan terhadap Return Saham ( $\operatorname{Sig} \mathrm{t}=0,278)$ ), hal ini tidak sesuai dengan hipotesis yang menyatakan bahwa DER berpengaruh negatif signifikan terhadap Return Saham karena DER tergantung pada fluktuasi pendapatan. Perusahaan dengan pendapatan yang stabil cenderung mempunyai kemampuan membayar hutang lebih baik dibanding perusahaan dengan pendapatan yang berfluktuasi, sehingga investor lebih nyaman dengan DER yang tinggi pada perusahaan dengan pendapatan stabil. Hal ini menyebabkan dengan regresi linier DER tidak berpengaruh secara signifikan karena stabilitas pendapatan tidak dimasukkan sebagai faktor pengkoreksi.

EPS Log berpengaruh positif signifikan terhadap Return Saham (Sig $\mathrm{t}=0,000)$, hal ini sesuai dengan hipotesisnya yang menyatakan bahwa EPS Log berpengaruh positif signifikan terhadap Return Saham karena karena laba bersih merupakan unsur yang sangat penting bagi perusahaan untuk meningkatkan investasi dan membayar dividen ke investor. Perusahaan dengan laba bersih yang meningkat akan semakin mampu menyisihkan dana untuk melakukan investasi (retained earning) untuk memperluas usahanya yang akhirnya meningkatkan pendapatan dan laba bersih di masa mendatang, dan semakin mampu membayar dividen ke investor. Dengan demikian laba bersih yang meningkat akan disukai investor yang akhirnya meningkatkan Return Saham.

Suku Bunga berpengaruh negatif signifikan terhadap Return Saham (Sig $\mathrm{t}=$ $0,000)$, hal ini sesuai dengan hipotesisnya yang menyatakan bahwa Suku Bunga berpengaruh negatif signifikan terhadap Return Saham karena Suku Bunga yang meningkat mengakibatkan. investor mengalihkan dananya ke instrument lain seperti obligasi sehingga returrn saham akan turun. Nilai Tukar tidak berpengaruh signifikan terhadap Return Saham (Sig $\mathrm{t}=0.067)$. Hal ini tidak sesuai dengan hipotesis yang menyatakan bahwa Nilai Tukar berpengaruh positif signifikan terhadap Return Saham karena variasi nilai tukar selama periode penelitian adalah sedang (dari 8.700 sampai dengan 10.300) sehingga pengaruhnya tidak signifikan terhadap Return Saham.

\section{Simpulan, Keterbatasan, dan Implikasi Hasil Penelitian}

Berdasarkan pengujian 108 data tahun selama 4 tahun, pengujian atas pengaruh return on equity, debt equity of ratio, earning per share, suku bunga dan nilai tukar terhadap return saham dapat disimpulkan sebagai berikut.

1. Return on equity tidak berpengaruh signifikan terhadap Return Saham. Kemampuan ekuitas perusahaan dalam menghasilkan laba tidak secara signifikan mempengaruhi pengembalian investasi yang telah ditanamkan investor di pasar modal. Secara teori proporsi ekuitas atas laba perusahaan 
berbanding lurus dengan harga. ROE yang tinggi berarti perusahaan mampu memanfaat modal yang dipercayakan investor atau yang dimiliki perusahaan dengan bak karena memberikan hasi lana yang tinggi.

2. Debt to equity ratio tidak berpengaruh signifikan terhadap Return Saham. DER sering diidentikan dengan risiko perusahaan. Proporsi ekuitas atas liabilitas perusahaan yang semakin besar berarti kemampuan modal perusahaan membayar utang semakin kecil. Hubungan DER dan return dapat menjadi positif jika investor meyakini bahwa utang yang dibuat oleh perusahaan untuk melakukan ekspansi usaha. Hubungan menjadi negatif atau tidak searah ketika DER yang diasumsikan investor sebagai risiko besar karena proporsi utang perusahaan semakin banyak dibandingkan dengan modal yang dimilikinya.

3. Earning per share berpengaruh positif signifikan terhadap Return Saham. Hal menari pada temuan penelitian adalah terbukti bahwa laba per saham merupakan informasi penting yang secara signifkan mempengaruhi harga saham sekaligus return saham.

4. Suku Bunga berpengaruh negatif signifikan terhadap Return Saham. Ketika tingkat suku bunga naik maka investor diasumsikan akan beralih investasi bukan pada pasar modal, namun pada pasar uang sehingga return saham akan turun. Hal ini terbukti pada penelitian ini berpengaruh, namun tidak berdampak turun namun searah. Hal ini menunjukkan bahwa laba adalah hal penting yang dianti investor, atau investor pada pasar modal Indonesia adalah investor loyal yang tidak bersifat spekulatif, namun lebih melihat aspek fundamental dibanding aspek teknikal.

5. Nilai Tukar tidak berpengaruh signifikan terhadap Return Saham. Nilai tukar dpt menjadi indikasi apakah investor lebih tertarik ke pasar uang atau pasar modal. Penelitian ini tidak berhasil membuktikan pengaruh nilai tukar terhadap harga saham atau lebih jauh return sebagaimana yang diukur dalam penelitian ini.

Riset yang dilakukan denga memfokuskan pada sektor industri tertentu memberikan kelebihan terkait refleksi hasilnya pada suatu industri tertentu yang memiliki karakteristik bisnis yang sama. Namun, juga memiliki kelemahan dalam hal daya generalisasinya. Terkait dengan hasil pengujian pengaruh return on equity, debt equity of ratio, earning per share, suku bunga dan nilai tukar terhadap return saham, berikut adalah saran-saran yang dapat diberikan.

1. Dalam memutuskan investasi saham di sektor konsumsi, investor sebaiknya memilih perusahaan dengan fundamental keuangan yang baik terutama EPS, dan mempertimbangkan keadaan ekonomi makro terutama perubahan suku bunga. Prinsip tersebut sebetulnya dapat digunakan pada sektor lainnya, akan tetapi investor harus mempertimbangkan kekhususan sektorsektor yang dipilih.

2. Investor sebaiknya mempertimbangkan juga faktor psikologis pasar dalam berinvestasi dimana harga cenderung tertekan saat pasar sedang pesimis ("bearish") sebagai contoh saat terjadinya krisis ekonomi global di akhir 2008 - awal 2009 dan merebaknya krisis financial di Eropa (terutama Yunani) di September 2011. Begitu pula sebaliknya saat pasar sedang optimis ("bullish"). Faktor pskologis pasar tersebut dapat diketahui melalui indikator teknik. Semakin pendek jangka waktu investasi maka semakin penting mempertimbangkan faktor tersebut

3. Dalam penelitian mendatang perlu menambahkan variabel-variabel lain yang mempengaruhi Return saham, misalnya faktor fundamental yaitu Revenue / pendapatan, sedangkan faktor makro misalnya Produk Domestik Bruto dan Inflasi.

4. Menambah rentang waktu penelitian yang lebih panjang sehingga diharapkan hasil penelitiannya lebih baik dan akurat. 


\section{Daftar Rujukan}

Ang, R.(1997).BukuPintarPasarModal Indonesia (The Intelligent Guide to Indonesian Capital Market). Jakarta: Mediasoft Indonesia.

Thobarry, A. A. (2009). Analisis pengaruh nilai tukar, suku bunga, laju inflasi dan pertumbuhan GDP terhadap indeks harga saham sektor properti (kajian empiris pada Bursa Efek Indonesia periode pengamatan tahun 2000-2008) (Doctoral dissertation, Program Pascasarjana Universitas Diponegoro).

Dewi, V. I. (2005). Analisis Pengaruh Faktor Fundamental dan Volume Perdagangan terhadap Total Return (Studi Empiris: Di Bursa Efek Jakarta) (Doctoral dissertation, Program Pasca Sarjana Universitas Diponegoro).

Fahmi, I. (2011). Analisis kinerja keuangan. Bandung: Alfabeta.

Fakhrudin, Darmadji, (2008). Pasar Modal di Indonesia, Jakarta, Salemba Empat.

Faried, A. R., (2008). Analisis Pengaruh Faktor Fundamental dan Nilai Kapitalisasi Pasar Terhadap Return Saham Perusahaan Manufaktur di BEI Periode 2002 s/d 2006, Tesis, Undip- Semarang.

Gitman, L.J., (2000). Principles of Managerial Finance. Seventh Edition. New York: Harper Collins College Publishers.

Halim, A. (2005). Analisis Investasi Edisi 2. Salemba Empat, Jakarta.

Hardiningsih, P., (2002). Pengaruh Faktor Fundamental Dan Resiko Ekonomi Terhadap Return Saham Pada Perusahaan Di Bursa Efek Jakarta: Studi Kasus Basic Industry \& Chemica, Jurnal Strategi Bisnis, Vol. 8, Des.

Husnan, S., (2005). Dasar-dasar Teori Portofolio dan Analisis Sekuritas, edisi 4 , UPP AMP YKPN, Yogyakarta.

Jensen, M. C., \& Meckling, W. H. (1976). Theory of the firm: Managerial behavior, agency costs and ownership structure. Journal of financial economics, 3(4), 305-360.

Hartono, J., (2010). Teori Portofolio dan Analisi Investasi, edisi 7, BPFE - UGM,
Yogyakarta.

Keown, M, William P., dan Scott, (2008). Manajemen Keuangan, Edisi 10, jilid 10, Indeks, Jakarta

Kewal, S. S. (2012). Pengaruh inflasi, suku bunga, kurs, dan pertumbuhan PDB terhadap Indeks Harga Saham Gabungan. Jurnal Economia, 8(1), 53-64.

Lestari, M. (2005, September). Pengaruh variabel makro terhadap return saham di bursa efek Jakarta: Pendekatan beberapa model. In Paper Seminar Nasional Akuntansi VIII.

Meta, R. S. (2006). Perbedaan Pengaruh Inflasi, Tingkat Suku Bunga Dan Nilai Tukar Rupiah/ Us Dollar Terhadap Return Saham (Studi Kasus Pada Saham Properti Dan Manufaktur Yang Terdaftar Di Bursa Efek Jakarta 20002005) (Doctoral dissertation, Program Pascasarjana Universitas Diponegoro)

Nathaniel SD, N. I. C. K. Y. (2008). Analisis Faktor-Faktor yang Mempengaruhi Return Saham (studi pada saham-saham real estate and property di Bursa Efek Indonesia periode 2004-2006) (Doctoral dissertation, program Pascasarjana Universitas Diponegoro).

Pancawati , Suryanto L. dan Chariri A., (2001). Pengaruh Faktor Fundamental dan Risiko Ekonomi terhadap Return Saham pada Perusahaan di BEJ: Studi Kasus Basic Industry dan Chemical, Jurnal Bisnis Strategi vol.8, Desember 2001, th VI, Program MM UNDIP.

Prihantini, R. (2009). Analisis Pengaruh Inflasi, Nilai Tukar, ROA, DER dan CR Terhadap return Saham (Studi Kasus Saham Industri Real Estate and Property yang Terdaftar di Bursa Efek Indonesia Periode 2003-2006) (Doctoral dissertation, Program Pasca Sarjana Universitas Diponegoro).

Bambang, R. (2001). Dasar-dasar Pembelanjaan Perusahaan, Edisi Keempat, Yogyakarta: BPFE. Denda Wijaya.

Subalno, S. (2009). Analisis Pengaruh Faktor Fundamental Dan Kondisi Ekonomi Terhadap Return Saham (Study Kasus Pada Perusahaan Otomotif dan Komponen Yang Listed di Bursa Efek Indonesia Periode 2003- 
2007) (Doctoral dissertation, Program Pasca Sarjana Universitas Diponegoro).

Suciwati, D. P. (2015). Pengaruh Risiko Nilai Tukar Rupiah terhadap Return Saham: Studi Empiris pada Perusahaan Manufaktur yang terdaftar di BEJ. Journal of Indonesian Economy and Business, 17(4).

Susilowati, Y. (2003). Pengaruh Price Earning Ratio (PER) terhadap Faktor Fundamental Perusahaan (Dividend Payout Ratio, Earning per Share dan Risiko) Pada Perusahaan Publik di Bursa Efek Jakarta. Jurnal Bisnis dan Ekonomi, 10(1), 51-56.

Sutrisno, (2006). Akuntansi Proses Penyusunan Laporan Keuangan, Ekonisia, Yogyakarta.

Syafaruddin, A. (1994). Alat-alat Analisis dalam pembelanjaan. Andi Offset, Yogyakarta.

Tandelilin, E., (2010). Analisis Investasi dan Manajemen Portofolio, Edisi Revisi, BPFE, Yogyakarta.

Utami, M., \& Rahayu, M. (2004). Peranan profitabilitas, suku bunga, inflasi dan nilai tukar dalam mempengaruhi pasar modal Indonesia selama krisis ekonomi. Jurnal Manajemen dan Kewirausahaan (Journal of Management and Entrepreneurship), 5(2), pp-123.

Wira, D., (2011). Analisis Fundamental Saham, edisi 1, Exceed, Jakarta.

Wijaya, T. (2012). Cepat menguasai SPSS 20 untuk olah dan interpretasi data.

Wulandari, C. (2005). Pengaruh Beberapa Faktor Fundamental terhadap Perbahan Harga Saham di BEJ. Skripsi FE UMM. 